\title{
AMATEUR POETRY FOR THE OCCASIONS: GROUPAXIOLOGICAL VOCABULARY AND CREATIVE SPEECH PRACTICES ${ }^{1}$
}

\author{
Natalia A. Kupina \\ Ural Federal University named after the first President of Russia B.N. Yeltsin, Yekaterinburg, Russia
}

\begin{abstract}
The article presents the results of linguistic, axiological, and stylistic analysis based on the collection of amateur poetry for the occasions "For such a small company..." (2019) published in Yekaterinburg. The collection includes poetic texts written in different years "by friends for friends". All the authors are philologists who graduated from Ural University in 1966. The study is essential, as it identifies the system of basic values reflected in the poems written for different occasions, which preserve the axiological code of Russian culture. The original texts provide new material for scientific analysis, which shows the literature-centrism of Russian culture and makes it possible to clarify the status of poetry for occasions. The intra-group poetry of this kind is found to have axiological vocabulary, which is characterized by being correlated to a certain chronotope, by presenting a system-forming integreme (in the analyzed texts it is the axiologeme of "friendship"), a special set of nominations of basic values, and by verbalizing value preferences. The axiological content of the congratulatory texts is specifically studied, wherein the motive of the family is developed. There are described creative speech practices: the development of unique image parallels that form the basis of comparative tropes, the use of technologies of transforming precedent texts and different types of puns. The authors' orientation on the aesthetic impression is proved to reinforce the worldview significance of the transmitted values of cooperation and spiritual unity.

Key words: linguistic axiology, axiologeme, poetry for occasions, identity, communicative convention, creative speech practices, cultural code, literature-centrism.

Citation. Kupina N.A. Amateur Poetry for the Occasions: Group Axiological Vocabulary and Creative Speech Practices. Vestnik Volgogradskogo gosudarstvennogo universiteta. Seriya 2. Yazykoznanie [Science Journal of Volgograd State University. Linguistics], 2020, vol. 19, no. 2, pp. 31-42. (in Russian). DOI: https://doi.org/10.15688/ jvolsu2.2020.2.3
\end{abstract}

\section{ЛЮБИТЕЛЬСКАЯ ДАТСКАЯ ПОЭЗИЯ: ГРУППОВОЙ АКСИОЛОГИЧЕСКИЙ ЛЕКСИКОН И КРЕАТИВНЫЕ РЕЧЕВЫЕ ПРАКТИКИ ${ }^{1}$}

\section{Наталия Александровна Купина}

Уральский федеральный университет им. первого Президента России Б.Н. Ельцина, г. Екатеринбург, Россия

Аннотация. В статье представлены результаты лингвоаксиологического и стилистического анализа, проведенного на материале опубликованного в Екатеринбурге сборника любительской датской поэзии «Для маленькой такой компании...» (2019), который включает стихотворные тексты разных лет, написанные «друзьями для друзей». Все авторы - филологи, окончившие Уральский университет в 1966 году. Актуальность исследования определяется необходимостью выявления отраженной в датской поэзии, сохраняющей аксиологический код русской культуры, системы общенациональных базовых ценностей. В научный оборот введен оригинальный текстовой материал, подтверждающий литературоцентризм русской культуры и позволяющий уточнить статус датской поэзии. Установлено, что внутригрупповая датская поэзия располагает аксиологическим лекси- 
коном, который характеризуется хронотопичностью, наличием системообразующей интегремы (в рассматриваемых текстах - аксиологема «дружба»), особым набором номинаций базовых ценностей, вербализацией ценностных предпочтений. Отдельно исследуется аксиологическое содержание текстов-поздравлений, в которых развивается мотив семьи. Описаны креативные речевые практики: разработка нестандартных образных параллелей, составляющих основу компаративных тропов, использование технологий трансформации прецедентных текстов и разные виды языковой игры. Доказано, что авторская установка на эстетическое впечатление усиливает мировоззренческую значимость транслируемых ценностей совместности, духовного единения.

Ключевые слова: лингвоаксиология, аксиологема, датская поэзия, идентичность, коммуникативная конвенция, креативные речевые практики, культурный код, литературоцентризм.

Цитирование. Купина Н. А. Любительская датская поэзия: групповой аксиологический лексикон и креативные речевые практики // Вестник Волгоградского государственного университета. Серия 2, Языкознание. - 2020. - Т. 19, № 2. - С. 31-42. - DOI: https://doi.org/10.15688/jvolsu2.2020.2.3

\section{Введение}

Сочинение стихов к датам - одна из сложившихся в России культурных традиций. Закрепившееся в узусе словосочетание датская поэзия устойчиво употребляется как иронизм в значении 'непрофессиональное стихоплетство, а не высокая поэзия Дании'. Имплицитная акротеза, основанная на лексической омонимии, блокирует возможность терминологического использования отмеченного словосочетания. Значит ли это, что любительские стихи являются объектом, выходящим за пределы филологических исследований? Думается, что на этот вопрос следует ответить отрицательно: «Даже плохой, слабый текст очень важен для отражения общей картины. Для того, чтобы определить литературную магистраль той или иной эпохи, нужно обращать внимание и на проселочные дороги» [Водолазкин, 2017, с. 311]. В стихах-однодневках, бережно хранящихся в домашних архивах, непосредственно реализуются базовые ценности, составляющие «интегративную основу и для индивида, и для социальной группы» [Леонтьев, 1996, с. 15]. Представляется также, что датские тексты выступают как одна из форм проявления литературоцентризма русской культуры. Транслируя определенные аксиологические предпочтения, они одновременно передают «авторскую установку на эстетически значимое творчество, хотя бы самое минимальное» [Григорьев, 1979, с. 7778], и уже поэтому принадлежат поэзии в ее широком понимании (см.: [Якубинский, 1986, c. 193]). «Текст с креативным заданием» [Крылова, 2013, с. 23], адресованный конкретному лицу (лицам), коллективу, преодолевает рутинность заданного датой культурного сценария (юбилей, свадьба, окончание школы / вуза, вручение награды и др.).

Датская поэзия функционирует в разных сферах непринужденного речевого взаимодействия. В определенный момент в центре внимания оказывается автор стихотворения. «Общность субъективных языковых картин мира участников общения делает возможной коммуникацию, служит ее основой» [Болотнова, 1992, с. 15], обусловливает адекватное восприятие целевым адресатом креативных новаций и аксиологического содержания стихотворного произведения. Приведем нестандартный пример. Литературовед, театральный критик Леонид Быков опубликовал свои тексты, объединив их в разные циклы: «календарная лирика», стихи, посвященные защитам диссертаций, юбилеям театральных коллективов Екатеринбурга, членам семьи и др. [Быков, 2017, c. 4-11]. В каждом конкретном случае обработка жизненного и языкового материала оказывается специфической, ориентированной на «свой круг». Реже датская поэзия складывается в собрание сочинений не одного, а разных авторов, членов одной группы (клуб по интересам, литературный кружок, корпоративное объединение и др.).

Данное исследование нацелено на выявление отраженной в датской поэзии, сохраняющей аксиологический код русской культуры, системы общенациональных базовых ценностей.

\section{Материал и методы исследования}

В статье анализируются материалы сборника «Для маленькой такой компании...», 
изданного в 2019 г. в Екатеринбурге и включающего стихи разных лет и комментарии составителя. Отдельно исследуется аксиологическое содержание текстов-поздравлений, в которых развивается мотив семьи.

Координация приемов лингвоаксиологического и стилистического анализа позволяет выявить аксиологически значимые номинации, а также охарактеризовать креативные речевые практики, реализованные в текстах стихотворений.

\section{Результаты и обсуждение}

\section{Групповой аксиологический лексикон: общая характеристика}

В настоящее время активно развивается лингвоаксиология, задачей которой является исследование вербального выражения базовых ценностей (универсальных и национально-специфических, групповых и индивидуальных). В науке активно используется термин «аксиологема». Отмечается, что аксиологемы - это «концепты (смыслы), которые воспринимаются носителями языка (точнее, лингвокультуры) как абсолютные ценности и игнорирование которых обществом, обслуживаемым данным языком, осуждается» [Кретов, Стародубцева, 2016, с. 140]. В эпоху перемен происходят сдвиги в системе ценностных ориентиров носителей лингвокультуры. В этой связи в процессе интерпретации ценностных смыслов с осторожностью следует относиться к аксиологическому максимализму. Так, связанный с культурной традицией концепт «удаль», входящий в перечень выявленных А.А. Кретовым и Ю.А. Стародубцевой аксиологем [Кретов, Стародубцева, 2016], нельзя назвать «абсолютным»: в текущее время «его игнорирование» вряд ли вызовет категорическое общественное осуждение.

Внутри разных социальных групп складываются подсистемы ценностей, при этом ценность, входящая в отдельную подсистему, не всегда абсолютна, безоговорочно одобряема обществом. Можно, однако, предположить, что ядерные ценности национальной русской культуры константны. Процедуры аксиологического измерения живого речевого существования, а также текстов разных стилей и жанров могут подтвердить или опровергнуть это предположение. В статье аксиологема понимается как вербальная номинация ценности, являющейся базовой для индивида и определенной группы лиц. Связь ценности с общенациональной культурой отмечается в ходе анализа.

Объективно следующее наблюдение: «На аксиологический статус каждого слова... влияют разнородные факторы: ситуация употребления, контекстное окружение, иллокутивная сила высказывания, а также неизбежный субъективный характер каждой коннотации» [Скляревская, 2019, с. 57]. Отдельные слова и словосочетания в контексте могут приобретать аксиологическую маркированность. Аксиологический лексикон, формирующийся в процессе реализации определенных речевых процессов, включает как собственно аксиологемы, так и аксиологически маркированные единицы. Наличием аксиологического лексикона, основанного на осознании групповой идентичности, отличается анализируемый сегмент датской поэзии.

Формула идентичности реализуется в предисловии к сборнику: $\mathrm{Mbl}$ однокурсники с филфака УрГУ, восемь выпускников 1966 года... (с. 3). Аббревиатура УрГУ (Уральский государственный университет), приобретая аксиологическую маркированность, выполняет интегрирующую функцию. Университет характеризуется как общий базис: УрГУ был нашей молодостью, совместным переживанием длиной в несколько лет, и эти годы были так плохо, так мало осмыслены... Чтобы это исправить, требовался коллективный разум, не иначе (с. 4).

На фоне осмысления ценностного жизненного опыта (семья, дети малье, работа, быт) формируется «Мы аксиологическое» [Гайда, 2016, с. 19]. Последнее предполагает наличие аксиологического центра, поддерживающего кооперативное речевое существование группы. Организующий центр группового аксиологического лексикона - номинация-интегрема дружба. Именно эта аксиологема задает отбор и реализацию вербальных знаков базовых ценностей ${ }^{2}$. Например:

(1) Нас восемь. Все мы держимся друг друга, / Хоть вовсе не очерчиваем круга. / Для нас всего 


\section{РАЗВИТИЕ И ФУНКЦИОНИРОВАНИЕ РУССКОГО ЯЗЫКА}

дороже - наша дружба, / Вот встретились - и ничего не нужно (ГЖ, 2009, с. 68$)^{3}$.

Узы дружбы проверены временем:

(2) В нынешнем году, под осень, / Встрече нашей - сорок восемь. / Два лишь года присчитаю - / Будет дружба золотая (ГЖ, 2009, с. 68).

Встречи друзей чаще всего приурочены к датам: дни рождения, юбилеи, новоселья, а также праздник Покрова, день «Рыб», Праздник Летнего Дня (с. 4). Тепло счастливых встреч сохраняет городская (екатеринбургская) и загородная география. Соответствующие номинации получают в текстах аксиологическую маркированность и интегрируют внутригрупповое общение:

(3) Неласков климат на Урале (ГЖ, 2003, с. 51);

(4) В зыбком мареве зноя арена / Лета нашего. Зной-аксакал... / И насмешливо щурится Гена, / И сверкает спаситель-Урал (ТМ, 2011, с. 71);

(5) Аллочка живет под новой крышей: / Лес недалеко, гора Уктус (ГЖ, 2008, с. 67).

Согревают сердца друзей знакомые адреса, названия улиц и районов Свердловска (Екатеринбурга):

(6) Все рядом... <...> Чапаева, 16 и УрГУ (ТМ, 2014, c. 77-78);

(7) ...Была Гурзуфская родной (ГЖ, 2004, с. 52);

(8) Зима нынче, ох, суровая, / Но греет квартира новая. / И ноги мерзнут, и тулово, / Но адрес теперь на Викулова (ТМ, 2016, с. 79);

(9) Там, на кресте Шаумяна и Ясной, / Были мы рядом, было прекрасно (ТМ, 2017, с. 82).

Настоящее не отодвигает воспоминаний о прошлом. При этом радости и горести, обретения и утраты неизменно связаны с ощущением личной принадлежности к внутригородскому пространству в проживаемое время:

(10) Наши неудачи и удачи, / Наши Юго-Запад и Химмаш. / Как всегда, смеемся мы и плачем, / Мир вокруг - он, несомненно, наш! (ТМ, 1986, с. 26).

Постоянное место встречи друзей - дачный домик в Сагре:

(11) Нас Сагра собрала... За окном тихо речка струится, / И под шелест ее и слова, и сердца в унисоH (BC, 2013, c. 91);
(12) Я махну на все дела / И на все свои проблемы / И куплю билет в Сагру, / Там совсем другие темы. / <..> Буду там согрета я / Дружескою лаской, / И на годик хватит мне / Той сагринской сказки... (ЭК, 2005, с. 94-95);

(13) Домик мой стоит над водой, / О, холмов и лесов благодать! / И народ, давно уже свой, / Понад Черной зову погулять (ГЖ, с. 84).

Вопреки суровому уральскому климату, согревают сердца родные улицы, встречи под крышей дома, который на время становится общим, общая память, взаимопонимание, чувство близости. Отмеченные выше единицы отражают специфику аксиологического лексикона и одновременно свидетельствуют о «географичности» стилевого облика анализируемых текстов.

Интегрема «дружба» обусловливает частотность аксиологически значимых собирательных номинаций: наш круг, народ, народ свой, компания, компашка, дружеская шай$\kappa a$, ватага. Иронизмы акцентируют коллективную установку на непринужденность общения. В кратких заметках, предваряющих раздел «Праздник Летнего Дня», встречи в Сагре предицируются как летнее счастье, проникнутое магией места (с. 86), а слово встреча $(u)$ функционирует как аксиологема.

Внутри дружеского круга формируется коммуникативная конвенция, предполагающая соблюдение установленных прав и обязанностей: ...строй общения... сложился сам по себе... <..> Существовали определенные тематические условия. О многом не говорили, потому что лишнее это было. <..> Mы не говорили о политике, почти не рассказывали анекдотов, не затрагивали работу, не обсуждали болезни и не жаловались на жизнь. И уж, конечно, не было никаких подковырок, эгоистического остроумия, честолюбивого желания первенствовать. Господствовала простодушная и справедливая уверенность в полном взаимном расположении (с. 86).

Базовая ценность - предполагающее естественную кооперативность «фатическое общение» (см.: [Винокур, 1993, с. 139-140]), основанное «не на иерархии, а на паритетных началах, хотя и в дружбе нередко возникает ситуативное лидерство» [Байкулова, 2015, с. 61]. В кругу друзей-филологов позицию коммуни- 
кативного лидера временно захватывает сочинитель стихотворного текста, аксиологическое содержание которого поддерживает обратную связь. Интенционально заданный контакт обусловливает неизменно положительный коммуникативный результат, связанный с коллективным ощущением духовного единения и родства. Интегрему «дружба» поддерживают вербальные сигналы общности: мbl, наш, свой, вместе, рядом, роднье. Например:

(14) Мы, как пчелы, к цветущему саду / Прилетим свой нектар собирать: / Мед беседы и сладости встречи (ГЖ, 2005, с. 62).

Друзья живут в ожидании встреч в ближайшем будущем:

(15) Милая речушка, до свиданья! / Не заплачу я при расставании, / Улыбаюсь. Радостная встреча / Нами на Сагре уже намечена (ГЖ, 2004, с. 59).

Дружба, возможность доверительных бесед, другоцентризм воспринимаются как чудо, ставшее реальностью вчера, не утраченное сегодня и устремленное в грядущее:

(16) Ой, где наш белый пароход, / Ой, где ты, рыбка золотая? / Давай-ка, рыбка, тихий ход, / Чтоб не доплыть совсем до края. / <...> Ой, будем дальше вместе плыть, / Ведь все же легче выжить в стае / И без потерь свой век дожить... / Мечты исполни, золотая! (ГЖ, 2005, с. 61).

Как следует из примеров, развитие аксиологического содержания интегремы «дружба» характеризуется хронотопичностью.

Безоговорочно одобряемые ценности (дружба, духовное родство, откровенные беседы), «фактор понимания целей коммуникантов, их отношений и ожиданий» [Эффективность коммуникации... 2019, с. 21] составляют основу сложившейся в традициях русской культуры коммуникативной конвенции, яркая примета которой - право на собственное рифмованное высказывание. Речевая креативность принимается друзьями как базовая ценность. Конвенциональные запреты не препятствуют речевой свободе: ...разговоры не утихали, было много шуток и взаимного подтрунивания, постоянно витал над головами смех, читались стихи и самодельные стишата (с. 86). Взаимное, общее не только не исключает, но и предполагает проявления персонализма.

\section{Авторские креативные практики и базовые ценности}

Автор датского текста предстает как реальное лицо, креативная языковая личность - человек, пишущий сочинение на заданную тему, рифмоплет. Погружение в мир слов, ожидание одобрительной реакции единомышленников доставляет ему эмоциональное удовольствие. Авторы анализируемых текстов - филологи по образованию, словесники (в широком понимании слова): редактор, корректор, преподаватель вуза, рекламщикк, библиотекарь. Исключение - актриса Ольга, но и она потом стала преподавателем сиенической речи (с. 3). В стихах неоднократно подчеркивается верность профессии:

(17) Еще не так давно мы здесь (в УрГУ) учились. / На этом пятачке и после мы кружились: / В Сельхозе - Эля, Дом Печати - мой, / Тамара - в универ, как в дом родной. / Червинская - она в «Полиграфисте» / Рекламой зарабатывать для жисти (ГЖ, 2009, с. 68).

Номинация профессии в форме множественного числа филологи (филологини) - устойчивый сигнал коллективной идентичности:

(18) Любезный именинник, / Наш Савин дорогой! / Твои филологини / Брели не из пустыни - / С окраины другой (ГЖ, 1999, с. 36).

Сочинитель, влюбленный в стихи и в слова (ТМ, 1983, с. 24), не стремится войти в литературу:

(19) Не отношусь к пиитам и эстетам, / И нет меня в их обществе речистом (ГЖ, 2004, с. 53).

Русский классический текст неизменно воспринимается как нетленная базовая ценность. Автор датского стихотворения осознает прикладной характер собственных поэтических опытов. Вторичность сочиненных по случаю строк подчеркивается, когда креативная идея связана с переработкой хрестоматийного прецедентного текста:

(20) Я прочитаю нашей Оле / Нравоучительный роман, / В котором Пушкина поболе, / Чем рифм известной Вам мадам (ГЖ, 1996, с. 29). 


\section{РАЗВИТИЕ И ФУНКЦИОНИРОВАНИЕ РУССКОГО ЯЗЫКА}

Автор открыто признает несопоставимость собственного $я$ с именами великих:

(21) Была б я Осип Мандельштам / Или поэтом Фетом... / Не справиться моим устам / С словарным элементом (ГЖ, 2003, с. 49).

Самоирония выражается в номинациях собственных творений: стишата, строчки, $c a-$ мопальные вирши.

Обращает на себя внимание отсутствие примитивизма, уместная реализация филологического мастерства, которое проявляется, в частности, в поисках формы. В сборнике представлены, например, акростихи, написанные на латыни. Они возвращают бывших сокурсников к учебным занятиям по древним языкам:

(22) Tempora mutantur Ab ovo (ad notanda) Magister dixit (litteram) Ad hominem (et cetera) Red-opto (carpe diem) Ex unge leonem.

(ГЖ, 2008, с. 66)

Акростих позволяет укрупнить статус адресата, передать без напыщенности искреннее чувство любви и дружеской привязанности, обозначить аксиологически значимую установку на оптимизм:

(23) Олюшка-солнышко,

Лет-то нам сколько же?

Юность ужель позади?

Шопена этюдами,

Колхозными буднями,

Ей-богу, сердца бередит.

Фольклорная практика,

Истмат с диаматами,

Любовь и стихи впереди.

Артистке записка...

Театр. За кулисами

Опять твой поклонник, иди.

Ведь было это в 60-х!

Ой, неужели нам столько же?

(ГЖ, 2001, c. 44)

Еще один пример:

\section{(24) Нонне Говыриной}

На дорогах мелькнет «шестерка»,

Ежедневно над трубами дым.

Говорят, и на белой скатерке
Остаются с годами следы.

Радость встречи следы разгладит,

Юность вспомнится - слаще хурмы.

Йорик бедный, только мы!!!

(ГЖ, 2007, c. 65)

Как свидетельствуют отмеченные в скобках инициалы, форма акростиха используется преимущественно одним автором. В текст внедряются «говорящие» звукосочетания, например звукобуквы и слоги, составляющие имя собственное:

(25) TA-MA-PA: Тамара там, где тра-та-та, / Тайфун, работа, суета. / И мать, сошедшая с ума / От слова ласкового МА! (ГЖ, 2004, с. 58).

Cp.:

(26) ЭльВИре ДаВИдовне. Разматываем свиток / Vi (ви) десятков лет. / Таких коллизий свито, / Каких не видел свет (ГЖ, 2004, с. 59);

(27) Восхищена душа, глава, / Восторг от слова - не забава. / Волшебны слова кружева. / Вовеки сладкая отрава (ГЖ, 2014, с. 76).

Разработанная креативная практика соединяется с метафоричностью, на базе которой формируется образное представление о магии слова.

Результат креативной деятельности нестандартные компаративные тропы ${ }^{4}$ :

(28) Ах, молодость все дальше уплывает... / Была она когда-то, не была? / Пинки и шишки щедро раздавая, / Она сиренью буйною цвела. / <..> Но даже нынче, сквозь пеньки и кочки, / Что метят наши склоны бытия, / Она мне шлет свои тире и точки: / «Спокойно, я с тобой. С тобою я» (ТМ. Пролог, с. 5).

Компаративные тропы погружены в предметный мир и непосредственно связаны с личностью и судьбой адресата:

(29) Околдовали поначалу, / Как Гала голая Дали, / И плеск волны, и гул причалов, / И голубые корабли. // Не пропиталась Алла солью, / Любви глубокой не случилось, / И терпеливою Ассолью / Не стала - так уж получилось (ГЖ, 2003, с. 51).

Образная аналогия может быть вмонтирована в контекст проживаемого времени (пример (30) о 1961 г.) или же спроецирована на давнопрошедшее, но закрепленное в культурной памяти время (пример (31)) : 
(30) Неопытны и кое-как одеты, / Не думали, бедны мы иль богаты. / Летели в космос корабли-ракеты, / Ибыли мы красивы и крылаты (ГЖ, 2001, с. 42).

(31) «Есть женщины в русских селеньях»,-/ Некрасов когда-то сказал, / Но он замолчал бы в смущеньи, / Когда бы тебя увидал. // Жилось им несладко, не спорю: / Муж - пьяница, гнет крепостной, / Но разве сравнится их горе / С твоею нелегкой судьбой? // < ... Да, прав был поэт, без сомнения, / Когда сочинял этот стих: / Есть женщины в русских селеньях, / И Нонна - одна из таких! (ВС, 2001, c. 42-43).

Компрессированный прецедентный текст усиливает воздейственность восприятия национально-специфического гендерного лингвокультурного типажа в его индивидуальном преломлении. Тот же автор (BC) укрупняет образ адресата, используя трансформированный с помощью лексических замен и вставки прецедентный текст. Шутливо-ироническая окрашенность сопровождает актуальное в советском прошлом имплицитное сопоставление (Ленин - партия) и связанную с ним вербализованную аналогию (история - Тамара):

(32) Нет, не буду с поэтом спорить я, / Вслед за ним повторяя с жаром: / «Если мы говорим - история, / Мы имеем в виду-Тамара!» (ВС, 2008, с. 66).

Подтекст во всех случаях понятен узкому кругу друзей, знающих многое о судьбе целевого адресата.

Стилевая черта анализируемых датских текстов - языковая игра, поддерживающая шутливо-ироническую тональность, характерную для речевого существования дружеского круга ${ }^{5}$. Установка на такую тональность позволяет говорящему обозначить собственную точку зрения без излишней категоричности. Авторами используются различные креативные технологии, в том числе игра частями слова, звучание которого легко восстанавливается в коммуникативно-предметной ситуации общения:

(33) Привет, боевая подруга / По Орску, УрГУ и ИРРО. / Декабрь, сгущается вьюга, / И жизнь нам немного угро... (ТМ, 1999, с. 38).

Сильные контекстные партнеры: Орск (место рождения ТМ и ОФ), аббревиатуры УрГУ и ИРРО (Институт развития регионального образования). Отмеченные номинации входят в лексикон автора и адресата - подруг дет- ства и юности, сохранивших дружеские контакты в «элегантном возрасте».

Обыгрывается кажущаяся невероятной ситуация рождения правнучки. Значимая часть слова (npa-) употребляется и как составляющая разных по значению существительных, и как окказиональная лексема. Языковая игра позволяет автору, любящему мужу, выразить восторг, радость, удивление, уверить адресата в том, что продолжение рода - залог вечной молодости:

(34) На рождение правнучки Ты позвонила мне с утра: «Поздравь меня, я стала пра!» И я подумал: «Вот те ра...» Еще, казалось бы, вчера В УрГУ тебя замучил праязык и прочая мура.

И, молодая той порой, Не думала, что станешь прой. Ты до сих пор шустра, бодра, И верю я, пришла пора, Она уже не за гора... Раздастся вновь звонок с утра: «Поздравь, ведь я уже пpanpa!»

(BC, 2008, c. 17)

Характерно, что использование «техники полуслова» трактуется специалистами как одна из «форм преобразования» языка современной поэзии (см.: [Фатеева, 2019, с. 120-121]).

В игровых целях используется звукоподражание. Например, в тексте, посвященном 40-летию супружеской жизни:

(35) Но уже и сейчас представляю отчетливо я, / Как годков через десять я лысым приду старикашкою, / Чтоб беззубо прошамкать: / «Ж жолотою ваш швадьбой, дружья!» (ВС, 2003, с. 16).

На основе фонетического созвучия возникает эффект «лексической ассимиляции» [Чернейко, 2016, с. 209]:

(36) Но смело сквозь холод и вьюги / Мы выйдем, презремши метель, / Отправятся дальше подруги, / Набрызгав «Шанель» на шинель (ТМ, 1999, c. 38).

Поддерживает языковую игру просторечная грамматическая форма презремши.

Следует отметить, что в ортологически безупречную ткань текста намеренно внедряются не только морфологические, но и акцент- 
ные, орфоэпические просторечные варианты, а также жаргонно-просторечные единицы:

(37) Когда ж в Сагру пора-охота, / Бери еды на цельну роту (ТМ, 2009, с. 18);

(38) Люд я́м на дальнюю дорожку / Хорош мешок из-под картошки (ТМ, 2009, с. 17);

(39) Приходилось отмечать / Пять, пятнадцать, двадцать пять. / Потерпи ешшшо немножко, / Будешь ягодка опять! (ТМ, 1985, с. 25);

(40) Мы ж не на халяву в этом доме: / Водки выпить и салат сметать (ВС, 1994, с. 27);

(41) Но нет страшней на свете преступления, / Чем от друзей замылить день рождения (BC, 1999, c. 15).

Эмоционально-эстетическая функция датских текстов основана на стратегическом использовании авторами экспрессивного потенциала национального языка, преобразовании языковых единиц, разработке приемов их обновления.

Способствующие преодолению автоматизма восприятия средства выразительности выполняют «функцию объединения группы» [Бартминьский, 2005, с. 141] и в этой функции оказываются органически связанными со средствами, обозначающими базовые, в том числе коммуникативные, ценности и аксиологические предпочтения друзей-филологов. Обе группы средств составляют основу языковой картины мира, сформировавшейся «в деятельности, которая является воплощением среды обитания» [Резанова, 2011, с. 28]. Аксиологически значимы включенные в биографическое время, связанное с пространством Урала, деятельностные сферы: семья, дом, дача, работа, встречи с друзьями и единомышленниками, кооперативная речевая коммуникация.

Стихи-поздравления содержат обусловленный жанром композиционный фрагмент, включающий нестандартные адресные пожелания. Лишь в отдельных случаях наблюдается реализация речевого стереотипа, содержащего прямые номинации базовых ценностей:

(42) Мы пришли своей подруге Томе / Счастья и здоровья пожелать (ВС, 1994, с. 27).

Типичной является трансляция ценностных смыслов и установок с помощью синтакси- ческой однородности. При этом аксиологическое содержание однотипно оформленных высказываний передается и эксплицитно, и имплицитно, как, например, в поздравительном послании к ВС:

(43) Неси, своя не тянет ноша. / Пусть завтра день взойдет хороший, / Не переводятся деньжишки / И улыбаются детишки. / Пусть жизнь бодрит, дарит и мучит, / Пусть все же кой-чему научит... / Успехов (сразу или с бою)! / Всегда together мы с тобою! (ТМ, 2009, с. 18)

Интегрема «дружба» и ее словесные варианты, передающие представления о единении, совместности, неразрывно связаны с базовыми ценностями семьи (любовь, добро, сердечность, мир, верность, труд, гостеприимство, открытость, домашние дружеские посиделки):

(44) Как скажешь сразу все про дом? / Дом ставят верой и трудом, / Любовью, чашкой чая ... / Но память сердца тоже здесь, / И все, что было, тоже есть, / И старые подружки / Гоняют чай из кружки (ТМ, 2013, с. 73-74).

Семейный лад, любовь, чувство прекрасного - аксиологические константы:

(45) Ясно понимая, что к чему, / Верно представляя перспективу, / Сохраняй любовь в своем дому: / Мир, как прежде, добрый и красивый (ТМ, 2013, c. 75).

Семью не разрушить, если рядом жена (хозяйка дома), муж и дети:

(46) Тома дома? / В доме Тома, / С мужем Мишею притом. / Если Тома будет дома, / Значит, будет этот дом! / <..> Тома дома? / В доме Тома, / С сыном Женею притом. / Если Тома будет дома, / Значит, будет этот дом! (ТМ, 1996, с. 28).

По-дружески, но с юмором оценивается материальное благополучие, достигнутое к золотой свадьбе:

(47) Почтим зеленый сей оазис / Под сенью хвойною дерев! / Семья имеет прочный базис, / Всегда имеет свой сугрев, / Квартиру, землю, баню, дачу, / И внуков-правнуков притом, / А также нас с тобой в придачу (ТМ, 2013, с. 19).

Поэтизируется концепт «счастье» в его связях с концептами «семья», «дружба»: 
(48) Счастья тебе, настроения, силы. / Чтобы семья тебя крепко любила, / Чтобы стремиться к миру, добру, / Чтобы держался дружеский круг (ТМ, 2017, c. 82).

Общенародное концептуальное представление о поэтическом предполагает задушевность - сокровенность, искренность, сердечность. При отсутствии «красивостей» задушевное передается аксиологемой душа в составе исповедальных лирических высказываний:

(49) Становимся строже и суше, / Храня свои тайны, свой берег. / Не каждому выложим душу, / Не каждому сразу поверим. // < .. > Пусть мало друзей, но сердечных, / Пусть верность одна, но большая. / Пусть радости меньше беспечной, / Но если уж есть - то без края (ТМ, 1976, с. 22).

Аксиологическая маркированность экспрессивов-интенсивов, сильных контекстных партнеров ключевой аксиологемы, синтаксическая семантика противительности актуализируют представления о настоящей дружбе, основанной на искренних чувствах близости, взаимного доверия. Живая душа дарит человеку многоцветие мира, обостряет чувства единения с природой:

(50) Искринка синяя те́плится в душе (TM, 1976 , c. 22);

(51) Аx, декабрь, с тобой моя душа! / Каждый день на воробьиный шаг / Ты сдвигаешь года жернова, / Даришь мне и звезды, и слова (ТМ, 2018, c. 83)

Как следует из приведенных примеров, эстетический эффект возникает на базе гармонического соединения аксиологической маркированности и эмоционально-экспрессивной окрашенности выразительных средств.

Завершает сборник (с. 97) не подписанное автором четверостишие:

(52) Две уж датой прикрылись подруги, / Ocтальные пока - с отточием... / Дети наши, правнуки, внуки, / Мы вас любим, и прочее, прочее...

\section{Заключение}

Авторы проанализированных текстов филологи, бывшие сокурсники, бережно сохраняющие тесный дружеский круг. В течение
50 лет в условиях непринужденного доверительного взаимодействия внутри группы сложилась коммуникативная конвенция, дающая право на свободное речевое творчество. Постепенно сформировался внутригрупповой аксиологический лексикон, характеризующийся хронотопичностью, наличием системообразующей интегремы «дружба», вербальных форм коллективной идентичности, номинаций ценностных предпочтений. Авторская аксиологическая интенция обусловливает направленное развитие описанных в статье креативных речевых технологий, с помощью которых осуществляется основанная на эстетическом переживании чувства духовной общности трансляция базовых, в том числе семейных, ценностей.

Будучи органической частью русской словесной культуры, любительская датская поэзия в целом является архиватором национального аксиологического кода. Такие характерологические признаки, как тематическая определенность, включенность обработанного авторами жизненного и языкового материала в проживаемое время, выдвижение на первый план восприятия событий, обладающих не только персональной и групповой, но и общенациональной значимостью, наличие особой прецедентной базы, позволяют рассматривать датскую поэзию как сегмент «литературы свидетельства» [Сухих, 2013, с. 19]. Представляется также, что проведенная на более широком материале систематизация импровизированных креативных находок будет способствовать осмыслению форм проявления литературоцентризма культуры, а также направлений развития системы выразительных средств русского языка.

\section{ПРИМЕЧАНИЯ}

${ }^{1}$ Исследование выполнено при финансовой поддержке РФФИ в рамках научного проекта №18-012-00382 А «Речевой быт семьи: аксиологическая реальность и методы исследования (на материале живой речи уральского города)».

Исследование поддержано программой 211 Правительства Российской Федерации, соглашение № 02.A03.21.0006.

The reported study was funded by RFBR according to the research project no. 18-012-00382 A "Everyday Communication Within a Family: 
Axiological Reality and Research Methods (Exemplified by Real Life Communication in Ural City)".

The reported study was supported by Act 211 of the Government of the Russian Federation, agreement no. 02.A03.21.0006.

2 По данным социолингвистических и психолингвистических экспериментов, в языковой картине мира горожан-уральцев концепт «дружба» закреплен как базовая системообразующая ценность (см.: [Вепрева, Купина, Ицкович, 2018]).

${ }^{3}$ Авторство, как это принято в источнике, маркируется инициалами, указываются также год написания стихотворения и страница.

${ }^{4}$ Теоретическое исследование компаративных тропов предпринято Н.А. Кожевниковой. Лексикографическое описание метафор и сравнений русской литературы XIX-XX вв. предложено Н.А. Кожевниковой и 3.Ю. Петровой [Кожевникова, 2009, с. 415-779; Кожевникова, Петрова, 2000].

${ }^{5}$ Параллельно отметим, что аксиологический потенциал языковой игры специально исследовался волгоградскими филологами (см.: [Аксиологическая лингвистика..., 2003]).

\section{СПИСОК ЛИТЕРАТУРЫ}

Аксиологическая лингвистика: игровое и комическое в общении, 2003 : сб. науч. тр. / под ред. В. И. Карасика, Г. Г. Слышкина. Волгоград : Перемена. $230 \mathrm{c.}$

Байкулова А. Н., 2015. Персуазивные прогнозы и сценарии в дружеской коммуникации и их коммуникативно-прагматические функции // Проблемы речевой коммуникации : межвуз. сб. науч. тр. / под ред. М. А. Кормилицыной. Саратов : Изд-во Сарат. ун-та. С. 59-70.

Бартминьский Е., 2005. Языковой образ мира: очерки по этнолингвистике. М. : Индрик. 528 с.

Болотнова Н. С., 1992. Художественный текст в коммуникативном аспекте и комплексный анализ единиц лексического уровня. Томск : Изд-во Том. ун-та. 312 с.

Быков Л., 2017. Второй состав: банкетная лирика и прочее. Фрагменты. Екатеринбург : Изд-во Урал. ун-та. 376 с.

Вепрева И. Т., Купина Н. А., Ицкович Т. В., 2018. Базовые ценности и их отражение в речевом пространстве уральского города // Вестник Российского фонда фундаментальных исследований. Гуманитарные и общественные науки. № 3 (92). С. 97-106.

Винокур Т. Г., 1993. Говорящий и слушающий: варианты речевого поведения. М. : Наука. 172 с.

Водолазкин Е. Г., 2017. Дом и остров, или Инструмент языка. М. : АСТ : Ред. Елены Шубиной. 384 с.
Гайда С., 2016. Стиль как вызов // Актуальные проблемы стилистики. № 2. С. 13-22.

Григорьев В. П., 1979. Поэтика слова. М. : Наука. 343 с.

Кожевникова Н. А., 2009. Избранные работы по языку художественной литературы / сост.: Е. В. Красильникова, Е. Ю. Кукушкина, 3. Ю. Петрова ; под общ. ред. З. Ю. Петровой. М. : Знак. 896 с.

Кожевникова Н. А., Петрова 3. Ю., 2000. Материалы к словарю метафор и сравнений русской литературы XIX-XX вв. Вып. 1. Птицы / отв. ред. В. П. Григорьев. М. : Яз. рус. культуры. 476 с.

Кретов А. А., Стародубцева Ю. А., 2016. Русские аксиологемы МАСа-2 // Политическая лингвистика. № 2 (56). С. 140-154.

Крылова О. А., 2013. Образность и тексты с креативным заданием // Филологические науки. Научные доклады высшей школы. № 3. С. 21-25.

Леонтьев Д. А., 1996. Ценность как междисциплинарное понятие: опыт многомерной реконструкции // Вопросы философии. № 4. С. $15-26$.

Резанова 3. И., 2011. Дискурсивные картины мира // Картины русского мира: современный медиадискурс / отв. ред. 3. И. Резанова. Томск : ИДСК-Е. С. 15-94.

Скляревская Г. Н., 2019. К вопросу о стилистических пометах как средстве экспликации языковой оценки // Аксиологические аспекты современных филологических исследований : тез. докл. Междунар. науч. конф. (г. Екатеринбург, 15-17 окт. 2019 г.) / отв. ред. Н. А. Купина. Екатеринбург : Ажур. С. 56-58.

Сухих И. Н., 2013. Русский канон : Книги XX века. М. : Время. 864 с.

Фатеева Н. А., 2019. Насколько «формальны» преобразования формы в современной русской поэзии // Известия Уральского федерального университета. Серия 2, Гуманитарные науки. T. 21, № 1 (184). С. 115-133.

Чернейко Л. О., 2016. «Лексическая ассимиляция»: среда действия и основания для типологии // Труды Института русского языка имени В.В. Виноградова РАН / отв. ред. Н. А. Фатеева. Вып. 7. С. 208-227.

Эффективность коммуникации: понятие, роль адресанта и адресата, основные приемы ее достижения, 2019 / под ред. О. Б. Сиротининой, М. А. Кормилицыной. Саратов : Наука. 236 с.

Якубинский Л. П., 1986. Язык и его функционирование. М. : Наука. 206 с.

\section{ИСТОЧНИк}

Для маленькой такой компании... / сост. Т. В. Матвеева. Екатеринбург : Ажур, 2019. 100 с. 


\section{REFERENCES}

Karasik V.I., Slyshkin G.G., eds., 2003. Aksiologicheskaya lingvistika: igrovoe $i$ komicheskoe $v$ obshchenii [Axiological Linguistics: Linguistic Play and Comic Commentaries in Communication]. Volgograd, Peremena Publ. 230 p.

Baykulova A.N., 2015. Persuazivnye prognozy i stsenarii $\mathrm{v}$ druzheskoy kommunikatsii i ikh kommunikativno-pragmaticheskie funktsii [Persuasiveness Forecasts and Scenarios in the Friendly Communication and Their Communicative-Pragmatic Function]. Problemy rechevoy kommunikatsii [Problems of Speech Communication]. Saratov, Izd-vo Saratovskogo universiteta, pp. 59-70.

Bartminskiy E., 2005. Yazykovoy obraz mira: ocherki po etnolingvistike [Language Image of the World: Essays on Ethnolinguistics]. Moscow, Indrik Publ. $528 \mathrm{p}$.

Bolotnova N.S., 1992. Khudozhestvennyy tekst $v$ kommunikativnom aspekte $i$ kompleksnyy analiz edinits leksicheskogo urovnya [Literary Text in the Communicative Aspect and Complex Analysis of the Lexical Level Units]. Tomsk, Izd-vo Tomskogo universiteta. $312 \mathrm{p}$.

Bykov L., 2017. Vtoroy sostav: banketnaya lirika $i$ prochee. Fragmenty [The Second Team: Banquet Lyrics and Other Things. Fragments]. Yekaterinburg, Izd-vo Uralskogo universiteta. $376 \mathrm{p}$.

Vepreva I.T., Kupina N.A., Itskovich T.V., 2018. Bazovye tsennosti i ikh otrazhenie $v$ rechevom prostranstve uralskogo goroda [Core Values and Their Reflection in the Speech of the Ural City]. Vestnik Rossiyskogo fonda fundamentalnykh issledovaniy. Gumanitarnye i obshchestvennye nauki [RFBR Journal. Humanities and Social Sciences], no. 3 (92), pp. 97-106.

Vinokur T.G., 1993. Govoryashchiy i slushayushchiy: varianty rechevogo povedeniya [The Speaker and the Listener: Variants of Speech Behaviour]. Moscow, Nauka Publ. 172 p.

Vodolazkin E.G., 2017. Dom i ostrov, ili Instrument yazyka [Home and Island, or Language Tool]. Moscow, AST Publ., Redaktsiya Eleny Shubinoy. 384 p.

Gayda S., 2016. Stil kak vyzov [Style as a Challenge]. Aktualnye problemy stilistiki, no. 2, pp. 13-22.

Grigoryev V.P., 1979. Poetika slova [Poetics of the Word]. Moscow, Nauka Publ. 343 p.

Kozhevnikova N.A., 2009. Izbrannye raboty po yazyku khudozhestvennoy literatury [Selected Works on the Language of Literature]. Moscow, Znak Publ. 896 p.
Kozhevnikova N.A., Petrova Z.Yu., 2000. Materialy k slovaryu metafor $i$ sravneniy russkoy literatury $X I X-X X v v$. Vyp. 1. Ptitsy [Materials for the Dictionary of Metaphors and Similes of the Russian Literature of the $19^{\text {th }}-20^{\text {th }}$ Centuries. Vol. 1. Birds]. Moscow, Yazyki russkoy kultury Publ. 476 p.

Kretov A.A., Starodubtseva Yu.A., 2016. Russkie aksiologemy MASa-2 [The Russian Axiologemes According to the Abridged Academy Dictionary of Russian ( $2^{\text {nd }}$ Edition $\left.)\right]$. Politicheskaya lingvistika [Political Linguistics], no. 2 (56), pp. 140-154.

Krylova O.A., 2013. Obraznost i teksty s kreativnym zadaniem [The Imagery and Lyrics with a Creative Job]. Filologicheskie nauki. Nauchnye doklady vysshei shkoly [Philological Sciences (Scientific Essays of Higher Education)], no. 3, pp. 21-25.

Leontyev D.A., 1996. Tsennost kak mezhdistsiplinarnoe ponyatie: opyt mnogomernoy rekonstruktsii [Value as an Interdisciplinary Concept: Experience of Multidimensional Reconstruction]. Voprosy filosofii [Russian Studies in Philosophy], no. 4, pp. 15-26.

Rezanova Z.I., 2011. Diskursivnye kartiny mira [Discursive Pictures of the World]. Rezanova Z.I., ed. Kartiny russkogo mira: sovremennyy mediadiskurs [Pictures of the Russian World: Modern Media Discourse]. Tomsk, IDSK-E, pp. 15-94.

Sklyarevskaya G.N., 2019. K voprosu o stilisticheskikh pometakh kak sredstve eksplikatsii yazykovoy otsenki [To the Issue of Stylistic Labels as a Means of Explication of Language Assessment]. Kupina N.A., ed. Aksiologicheskie aspekty sovremennykh filologicheskikh issledovaniy: tez. dokl. Mezhdunar. nauch. konf. (g. Ekaterinburg, 15-17 okt. 2019 g.) [Axiological Aspects of Modern Philological Investigations. Proceedings of International Scientific Conference (Yekaterinburg, October 1517, 2019], Yekaterinburg, Azhur Publ., pp. 56-58.

Sukhikh I.N., 2013. Russkiy kanon: Knigi XX veka [Russian Canon. Books of the $20^{\text {th }}$ Century]. Moscow, Vremya Publ. 864 p.

Fateeva N.A., 2019. Naskolko «formalny» preobrazovaniya formy v sovremennoy russkoy poezii [How "Formal" Are Transformations in Modern Russian Poetry?]. Izvestiya Uralskogo federalnogo universiteta. Seriya 2. Gumanitarnye nauki [Izvestia. Ural Federal University Journal. Series 2. Humanities and Arts], vol. 21, no. 1 (184), pp. 115-133.

Cherneiko L.O., 2016. «Leksicheskaya assimilyatsiya»: sreda deystviya i osnovaniya dlya tipologii ["Lexical Assimilation”: Its Scope and Basis for a Typological 


\section{РАЗВИТИЕ И ФУНКЦИОНИРОВАНИЕ РУССКОГО ЯЗЫКА}

Classification]. Fateeva N.A., ed. Trudy Instituta russkogo yazyka imeni V.V. Vinogradova RAN [Proceedings of the V.V. Vinogradov Russian Language Institute], iss. 7, pp. 208-227.

Sirotinina O.B., Kormilitsyna M.A., eds., 2019. Effektivnost kommunikatsii: ponyatie, rol adresanta i adresata, osnovnye priemy ee dostizheniya [Effectiveness of Communication: Concept, Role of the Addresser and Addressee, Main Methods of Achieving]. Saratov, Nauka Publ. 236 p.
Yakubinskiy L.P., 1986. Yazyk i ego funktsionirovanie [Language and Its Functioning]. Moscow, Nauka Publ. 206 p.

\section{SOURCE}

Matveeva T.V., ed. Dlya malenkoy takoy kompanii... [For such a Small Company...]. Yekaterinburg, Azhur Publ., 2019. 100 p.

\section{Information About the Author}

Natalia A. Kupina, Doctor of Sciences (Philology), Professor, Department of Russian Language, General Linguistics and Speech Communication, Ural Federal University named after the first President of Russia B.N. Yeltsin, Lenina St., 51, 620000 Yekaterinburg, Russia, natalia_kupina@mail.ru, https://orcid.org/0000-0002-4154-7323

\section{Информация об авторе}

Наталия Александровна Купина, доктор филологических наук, профессор кафедры русского языка, общего языкознания и речевой коммуникации, Уральский федеральный университет им. первого Президента России Б.Н. Ельцина, ул. Ленина, 51, 620000 г. Екатеринбург, Россия, natalia_kupina@mail.ru,https://orcid.org/0000-0002-4154-7323 